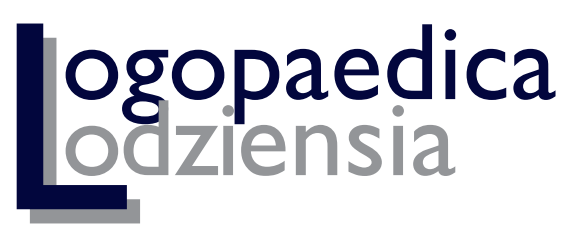

$\mathrm{Nr} 4(2020)$

D0l: http://dx.doi.org/10.18778/2544-7238.04.02

Renata Gliwa* iD

\title{
Speech Therapy Case Study of Patient Diagnosed with the Frontal Psychoorganic Syndrome ${ }^{1}$
}

Logopedyczne studium przypadku pacjentki z rozpoznaniem zespołu psychoorganicznego czołowego

Keywords: psychoorganic syndrome (POS), dementia, impaired competence and interaction, communication and language skills

Słowa kluczowe: zespół psychoorganiczny, otępienie, zaburzenia kompetencji i sprawności: interakcji, komunikacyjnych, językowych

\section{Introduction}

The psychoorganic syndrome a deviation in the mental state due to damage or dysfunction of the brain structures [see Prusiński, 1998; Kozubski, Liberski, 2014]. It is associated with the occurrence of mental disorders manifested in the behavioral, socio-emotional, cognitive and therefore also communicative sphere [see $\mathrm{Bi}$ likiewicz, Strzyżewski, 1992; Olszewski, 2008; Panasiuk, 2015a; 2015b]. According to ICD-10, there are several clinical forms of the syndrome: characteropathic type (F07); mental retardation type (F70-F79) and dementia type, being the subject of this paper [see ICD-10, 2008].

The syndrome includes [see Herzyk, 2005; ICD-10, 2008; Panasiuk, 2015a]:

- dementia in Alzheimer's disease (F00), with early onset (F00.0) and late onset (F00.1), atypical or mixed type dementia (F00.2), unspecified dementia (F01.9);

\footnotetext{
* University of Lodz, Faculty of Philology, Department of Polish Dialectology and Logopaedics, 171/173 Pomorska street, 90-236 Łódź, e-mail: renata.gliwa@uni.lodz.pl, ORCID: https://orcid.org /0000-0003-2231-9197.

1 A reprint of the article in Polish was published in the „Dissertations of Language Committee of Lodz Learned Society" 2020.
} 
- vascular dementia (F01), of acute onset (F01.0), multi-infarct (F01.1), subcortical (F01.2), mixed cortical and subcortical (F01.3), other (F01.8), unspecified (F01.9);

- dementia in other diseases classified elsewhere (F02): in Pick's disease (F02.0), in Creutzfeldt-Jakob disease (F02.1); in Huntington's disease (F02.2), in Parkinson's disease (F02.3), in human immunodeficiency virus [HIV] disease (F02.4), other (F02.8);

- unspecified dementia (F03);

- organic amnesic syndrome, not induced by alcohol and other psychoactive substances.

In the Polish logopedic literature there are few studies devoted to the analysis of communication disorders in the course of psychoorganic syndrome [see Panasiuk, 2015a, pp. 1025-1058; 2015b, pp. 81-112].

\section{The aim of the work}

The aim of the paper is to assess the competences as well as interaction, communication and language skills of the patient diagnosed with the psychoorganic syndrome; to indicate psychogenic symptoms determining interaction disorders observed in the subject; to identify the pathomechanism of the disorder.

\section{Methodology}

The diagnostic process in the psychoorganic syndrome requires using the qualitative-quantitative approach, it must also account for multi-specialist assessment as the course of disease processes may be diversified and include, to a varying degree, disorders of behaviour control, emotions, cognitive functions and even motor skills [see Panasiuk, 2015a; 2015b].

The speech therapy examination was preceded by getting acquainted with the data concerning the medical history of the patient as well as information from the interview with the guardians of the subject and the subject [see Siuda, Opala, 2012; Panasiuk, 2015a; 2015b].

A Mini Mental State Examination and The Clock Drawing Test [see Krzymiński, 1995] were used for screening for cognitive impairment. In order to assess the interaction, communication and language competence and skills the researcher used Skala komunikacji niewerbalnej (The Scale of Non-verbal Communication) [Pąchalska, 2012]; a test by Szumska included in Metody badania afazji (Methods of Examining Aphasia) [Szumska, 1980], tests aimed at assessing the ability to create a narration (autonarration, renarration [Szepietowska, 2000], illustration description [Szumska, 
1980]). Other tests which were carried out include a terminology test ${ }^{2}$, tests of understanding metaphors ${ }^{3}$, tests of understanding situational humour [Goodglass, Kaplan, 1972, tests 7-8], verbal fluency test ${ }^{4}$ (including semantic fluency: names of animals, sharp objects, cities, countries, rivers; formal fluency: $f, k$ sounds; as well as fluency with regard to verbs: the task of the subject was to answer the question what is the man doing?).

\section{Case description}

The patient was 68 years old at the time of conducting the research ${ }^{5}$. She has two children. Nowadays she is taken care of by her family. She obtained secondary education, she was an administration worker. She is right-handed. According to her daughter, she used to have well-developed social relations.

She was diagnosed with the frontal psychoorganic syndrome at the age of 65 . The primal disturbing symptoms of the disease were noticed by the family approximately 8 years earlier. Considerable irritability and emotional lability appeared first. According to her daughter, her mother became quarrelsome, sometimes alogical, she gradually withdrew from social relations, she grew suspicious.

The patient's condition worsened considerably about 4 years ago after a fall from her height, she broke the thigh bone, but according to the data she did not suffer from any head injury. After the accident it was observed during physical rehabilitation that she suffered from lack of motivation to undertake any physical and mental effort as well as memory disorders. She was referred to neurological and psychiatric consultation and subsequently she was diagnosed with the psychoorganic syndrome.

A recent CT scan indicates the presence of numerous pathological changes, particularly intensified in the area of the frontal lobes as well as cortical and subcortical atrophy with widening of the ventricular system and CSF spaces. Visible demyelinating areas in the region of the frontal lobes were attributed to chronic ischemic processes. In the opinion of the neurologist, most pathological changes observed in the patient correspond to basal frontal lobe disorder of dementia type.

The patient obtained 15 points in the Barthel Index (BI). Apart from eating she does not perform self-care tasks independently (she does not feel the need to do so).

\footnotetext{
2 A test elaborated on the basis of proposals by Pąchalska [2012].

3 Tests elaborated on the basis of proposals by Pąchalska [2012]. The task of the subject was to explain the meaning of the following metaphors: you scratch my back and I'll scratch yours, it is coming down in buckets, heart of stone, diamond cut diamond.

4 The verbal fluency test was elaborated and assessed with references to the following publication: Szepietowska, Gawda [2011]; Szepietowska, Lipian [2012]; Piskunowicz et al. [2013]; Sitek et al. [2014]. The time to perform a task in each test is 60 seconds [cf. Piskunowicz et al., 2013].

5 The researcher obtained consent to carry out the research.
} 
Characteropathy is manifested in the subject by lack of self-cognition and selfconsciousness, insight disorders, false convictions about the external surroundings, lack of awareness of the disease and incomplete consciousness of the objectively existing disorders [see Herzyk, 2005].

The patient displays considerable changeability with regard to behaviour and emotion control, shifting easily from the state of considerable euphoria to short outbursts of anger and aggression. She concentrates on topics connected with sex very often, yet there are a form of verbal aggression, a kind of sexual disinhibition, rather than just jocular comments [see Łuria, 1976; Olszewski, 2008]. In addition, the subject hardly ever undertakes any activity, her behaviour is characterized by lack of drive and spontaneity. She also lacks persistence in performing intentional acts. The subject engages in activities only if she is convinced that they will be successful, and she abandons her task if she anticipates any difficulties, often manifesting quite aggressive behavior at the same time.

The patient fulfils her needs in disregard of the consequences and social rules (leaving any object with her results in a theft). She has a tendency to gluttony [see Olszewski, 2008]. It is also possible to observe disruptions to the cerebral processes of stimulating and inhibiting activities in the patient, e.g. she constantly folds and unfolds a blanket. The subject's thinking is characterized by concretization of her attitude towards reality.

Nowadays the patients spends most of her time in bed. In the opinion of the doctor she is capable of moving on her own. The verticalization of the patient was not possible, however, due to her resistance. According to her daughter, the subject moves on her own during the night (not infrequently different objects were found in her bedsheets in the morning).

The medicines taken by the patient have anticoagulant, anti-bedsore and analgesic effects.

\section{Research results}

\section{Autopsychic and allopsychic orientation}

The subject was diagnosed with severe dementia on the basis of the MMSE test results (9 points). The patient has impaired autopsychic orientation. She provided only basic information about herself, which anyway was heavily dependent on her mood. She was unable to tell the story of her life but she answered questions concerning her. In her answers she made factual mistakes, omitted important facts, reversed episodes and confabulated (e.g. she maintained that she had no children, on another occasion she mentioned names of her two children, and then of three children) e.g. (What is your name?) My name i... is... yes Jadwiga [...]. (How old are you?) Sorry 
honey? (How old are you?) How old... I haven't counted lately, 'cause they all mixed up and I'd like to apologize... (How old are you more or less?) I can't be more or less, as I am in... an inane girl. (What was your job?) I'm a paramedic, learning education and conversation with the owners, no care... (What did this job involve?) It didn't involve anything, all they did was shit and fart...

She occasionally correctly recalled information concerning her surroundings (allopsychic orientation), most of the time, however, her answers were inadequate, e.g. (What country do we live in?) We used to live! [the subject corrected me] In Russia, reaching some... some specific thinking words which allow to ask for something or apologize, a situation... (What country are we in?) Beloved Poland, born, peed and w... wet...

\section{The Clock Drawing Test}

Many attempts were made to conduct a task concerning clock gnosis, yet all attempts were of no avail. Refusal to do the test may point to the lack of motivation resulting from impairment of executive functions. As the patient tended to refuse to accomplish the tasks which she expected to fail at, it may be assumed that she suffers from disorders in planning, impairment of visual memory, impairment of the ability to visualize and, consequently, visuospatial impairment and disorders in abstract and notion thinking [see Krzymiński, 1995; Schulman, Shedletsky, Silver, 1997]. This conclusion is confirmed by the subsequent tests (described later in the paper) which point to concretization of the subject's thinking.

\section{Assessment of dialogue skills}

The structure of the dialogue co-created by the subject is extremely distorted [see Warchala, 1991; Domagała, 2007]. The patient takes part in the dialogue but rarely initiates it. The dialogue is hardly ever aimed at satisfying her physical needs.

She fills the dialogue with mimicry and gestures adequately to the intonation. She usually does not observe the principle of turn-taking, her utterances tend to be monologues, she does not strive to keep the dialogue going. She asks few questions but she asks them correctly, using adequate intonation. Her answers are sometimes adequate only at the beginning of the utterance, then she loses purpose and strays from the subject, e.g. (What is it? [a woman's face]) she isn't similar to anyone and she's not pretty, she's got plain eyes... if her eyes were as pretty as yours she'd be a beauty..., I only have eyes for you... Her replies are riddled with logical, semantic, inflectional and syntactic errors. It is also possible to observe the amnestic loss of words yet despite this no descriptive constructions were noticed. Instead, different types of semantic and phonetic paraphrases appeared. In addition, the utterances of the patient were characterized by the phenomenon of the pressure of speech, i.e. an increase in spontaneous speech as compared to expectations e.g. (How are you feeling?) So so, like an old person who comes to agreement with history and asks for a bill for 
bad behaviour...; with a simultaneous poverty of content, e.g. (What did you have for breakfast today?) I didn't eat anything, a small cup, not big so that it may go through the throat and not stop in uneaten food in the throat, these are kind... After a distractor had appeared, the subject did not return to the subject (distracted speech). Her utterances were very often faulted and surprising, e.g. I have a headache from listening to such nonsense... (are you feeling bad?) I never feel like a stupid one who talks nonsense because of the lamp but people do so.

In the case of persons who she likes she used greeting formula adequately. In addition, they were often accompanied by great emotional load, e.g. Good morning, my dear princess!

\section{Assessment of speech comprehension}

The tests whose aim is to assess decoding of speech by the patient revealed slight difficulties in the scope of understanding single words (names of objects, activities, body parts, etc.) and simple sentence constructions, such as: close your eyes and open your mouth; please point to the floor, ceiling and wall. The subject accomplished most tasks of this kind correctly (80\%). No psychomotor retardation was observed, and this time the patient refrained from commenting on the tasks.

She failed to perform instructions which required understanding complex syntactic, semantic and logical relations between words, such as: your father's brother is your..., or please open the notebook and put a pencil on it. Hence she had considerable problems with understanding syntactic constructions which encode logical rather than direct relations or sentences containing pronoun constructions. She found it more difficult to understand constructions with the attributive genitive than with the partitive genitive [see Łuria, 1976].

The patient did not understand situational humour [Goodglass, Kaplan, 1972, tests 7-8], she explained the presented metaphors in a concrete manner, which suggests global disorders of language functioning. Disorders of this type may be analyzed in the context of executive dysfunctions: the tendency to interpret figurative expressions in a way which is too concrete and literal results not only from the loss of linguistic knowledge but also the inability to block automatic conceptual associations which the subject was incapable of either controlling or inhibiting (a defect of executive control rooted in the language) [see Jodzio, 2008; Domagała, 2015].

\section{Assessment of realization of automated sequences}

The subject was not capable of reproducing automated sequences, e.g. names of the days of the week or months, which requires involvement of right-brain strategies [see Szepietowska, Lipian, 2012]. There were several attempts at this, all of which were to no avail, e.g. (Please name the days of the week.) A day of the week, this one that is sitting and writing on the written... [the subject comments a photograph from the newspaper lying next to her] That one, a... a nice lady and she's lying on this couch, 
she's early and she's keeping something her paws, and I'm only keeping my paws near the neck... Even in a situation when the researcher began the sequence the subject refused to continue it: (Please count from 1 to 10.) I don't care a damn about men, they're crappy! Shitty! Stinky! (Let's count from 1 to 10, one, two, three what is next?...) As we count that it is not counted in reality somebody doesn't pay attention to this person... (Please give names of the months, I will start January, February, what is next?) I don't care about Jan... na ry... [clearly distorted words January, February] I mean, shit, she's got an arse and he stinks...

\section{Assessment of repetition activity}

The subject did not do most of the tasks concerning repetition 6 . However, she did not have such significant abnormalities in the relationship between the auditory and kinaesthetic analyzer so as to speak of an impairment of the basis of this activity [see Panasiuk, 2013]. There are a number of conditions of efficient repetition: the first one involves the efficient activity of the auditory cortex, the second one - of the postcentral (kinesthetic) cortex conditioning accurate articulation, the third one consists in the possibility of switching from one articuleme to another, which requires plasticity of the premotor area of the left hemisphere, the third one is the possibility of disregard well-established stereotypes and inhibiting peripheral alternatives, which is realized with the direct activity of the frontal lobes [see Łuria, 1976, pp. 338-339].

The basic deficit preventing the patient from completing the task was probably related to the inability to understand the instruction and assess its purpose, which is manifested by her specific way of responding to the requests: (Please repeat ' $a$ ') $A$ is $a$, and not $b .$. (Please repeat 'o'.) Oh!... what do you mean, my dear?... (Uuu. Please repeat ' $u$ '.) Do you mean l...loo? (Please repeat 'a'.) A.? What is a? A and ę? If you repeated yourself this must be hard... (Please repeat ' $k$ '.) $K$, crap, we don't give a shit! And don't... (Please repeat 'p'.) I don't need any pee! Or any shit...

During the test of sentence repetition the subject commented on the sentences which she heard but she failed to repeat them, e.g. (Please repeat: 'The dog barks') Every dog in the world barks if some person doesn't appeal to it or it doesn't like him or her, it does not wonder whether to bite the dog in its arse or not, it just snee at it!... (Please repeat 'Mum is cookinglunch.) So this girl is hungry and she doesn't want to go hungry in her flat, she's going on and on to her mum about how hungry she is and her mum hasn't made lunch yet. (Please repeat: 'A boy is running through the green meadow.) A silly boy with his silly mother (perseverance to the previous sentence). The subject is, therefore, in capable of copying linguistic symbols.

6 A significant role in the repetition activity is attributed to the arched bundle, which concentrates the associative fibres connecting the front and back of the 'speech area', determines the combination of the sensory and motor aspects of the speaking activity, including repetition [Panasiuk, 2013, p. 50]. 


\section{Assessment of name-giving}

The subject was shown 50 illustrations representing 10 semantic categories and 20 illustrations presenting activities. She gave correct names to 11 nouns and 5 verbs. The subject had, therefore, considerable problems with referring symbols to the external reality. The errors concerned using the name of the higher-function category, e.g. (a rose) And these... like flowers for a chocolate box...; an incorrect name but belonging to the same semantic category, e.g. (shoes) Slippers, legs on the calves...; an incorrect name but belonging to an adjacent semantic category, e.g. (a fork) This is an awful ordinary snack after a meal; an incorrect name related to the correct context, e.g. (a comb) A bottle to comb your napper...; (a bed) A box for sleeping. Moreover, errors in perception were noted, e.g. (a watch) Visually, well suggestively all the rings seem sharpened and pun... punctured so that we know which ring shows all the time. In a situation when the patient lacked a word she used 'paradescriptive' constructions, e.g. (umbrella) This is protection against an accident or after an accident, going additionally...

Essentially, all responses were accompanied by pressure of speech, e.g. (a glass with tea and a spoon) A stupid yob! An empty glass filled with empty! Some empty liquid and a spoon, and the spoon put outside.

Another quite characteristic phenomenon was that the subject tended to give answers only fragmentarily connected with the presented illustration, e.g. (chair) The toe is standing on the floor, and in addition you don't need to worry that it won't go to sleep or sit. The patient tended to have considerable problems with recognizing the designatum, which was related to concretization of the illustrations presented: (telephone) These are some extras plugged to an ordinary box, to an ordinary box, like such a box in the Spanish language. The concretization of the reality or perceived images was manifested in the form of fragmentary perception of the designata presented in the illustrations, e.g. (open notebook) Two separate pieces of rubbish torn separately. Some kind of perseverations were noted but without giving the name required, e.g. (hair brush) Some stick [the subject turns photographs on her own and gives a name the following illustration], (comb) And here another stick...

The primary deficit seems to be predominantly connected with disorders of visual perception, to a lesser extent a lack of acoustic model of the word (functions of audio and verbal systems of the left temporal area) or disorders of finding the appropriate wording due to the lack of the ability to inhibit alternative words (connected semantically, morphologically or phonetically, the so-called blockers [see KielarTurska, Byczewska-Konieczny, 2014]), the phenomenon related to the weakening of the so-called 'motility' of nervous processes (lower parts of the pre-motor area of the left hemisphere and left frontotemporal area) was relatively rarely observed [see Łuria, 1976]. 


\section{Assessment of verbal fluency}

The subject was not able to accomplish tasks with regard to formal verbal fluency, semantic fluency as well as verb fluency, e.g. (Please give as many words as possible beginning with 's.) Someone... someone will want to, they'll na... name every word, 'cause they'll cope with no other, 'cause you never know what they'll come up with, maybe some key deposit and twist a c...crazy topic... (Please give as many names of animals as possible.) I don't know animals 'cause I'm not a monkey! Other monkeys are monkeys! A problem... I've got a problem with the name... (What can a man do?) Well... of course they may go out, in a pot, cook in a pot, under, under underlined with centrimetres centri... centrimetres, out of which shit that is...

There are several reasons for the lack of verbal fluency: firstly, impairment or loss of basic skills: the ability to understand the oral instruction and, secondly, the breakdown of semantic networks and impoverishment of the semantic glossary. Besides, dysfunctions may concern faulty organization and strategy of thinking and these are connected with the loss of general cognitive flexibility, executive disorders, memory and attention disorders [see Jodzio, 2006].

\section{Assessment of the narrative skill7}

The description of autonarration was provided in the subsection on autopsychic orientation. During the renarration test the patient was asked to listen to two short stories and summarize them. The text of one of them is presented below:

There was a boy who went to a big city to do some shopping. His dog wailed longing for his master and finally it broke off the chain and ran towards the city. When the boy was going out of the shop he saw his dog barking in front of the shop. His dog found him in a big city [Szepietowska, 2000, p. 23].

As the man was go going out of the city he met a big dog and he knew who who the dog belonged to, why this dog lives so close and not..., it is not going anywhere to find anyone, apologize stay with someone so that he doesn't have problems with his heart and with the sorrow that someone judged him unfairly, that misinterpreted his behavior in a few bigger minutes.

The way the subject related the texts which were read to her points to the loss of coherence of the narration, the patient was unable to construct the narrative scene, sustain the narrative line or order the events, she only made fragmentary references to the presented content. The subject was, therefore, incapable of putting phenomena into a structural whole, there is a total lack of pragmatic coherence. The time factor is of key importance here as the subject had a considerable problem with

7 The topic of the theory of narration and its description is discussed more broadly by Domagała [2015], Woźniak [2005], see also Grabias [2015]. 
repeating the sentences. Therefore it comes as no surprise that she was unable to reconstruct more extensive texts which require longer processing time. The main reasons for the disorders include impairments of the working memory and feedback control. The subject lost the data necessary to construct the utterance very quickly and the lack of feedback control together with long processing time made her stray from the subject, which was accompanied by a breakdown of intratextual relations and presence of accidental associations [see Woźniak, 2014].

The aim of the subject in the following test was to say what she can see in the photograph [see Szumska, 1980]: These are exorbicious situations which show different behavior types to theirguys... (Please describe the illustration) Oh, he's got himself in and he's standing there... he's wearing a shirt and pants... as you can see, sir... Madam, I mean [the subject corrected herself] he sees you and he's got to go and stand beside and not walk into him, they warn, they don't warn the queue to be taken.

Also here the subject fragmentarily built references to the photo presented to her, she did not use the usual formulas to start the description, she tended to notice only one dimension. There is no hierarchical structure in her utterances. The subject was unable to give an overall assessment of the picture, she fails to notice and she does not take into account the principles of presentativeness of events.

\section{Assessment of calculation skills}

The patient named $95 \%$ of presented numbers correctly, the few mistakes which she made include errors resulting from the wrong order of digits in numbers e.g. (12) twelve thousand (102) two thousand. The significant deficit concerned the recognition of symbolic signs: the patient identified the point as the multiplication symbol. e.g. (5.) five times, (3.) three times nine, (9.) nine times six, (6) [...]. She failed to recognize Roman numerals, e.g. (IV) one quarter, (VI) one fifth. She referred correctly to only one symbol of mathematical operations (+) uuu a plus, (-) unfinished stupidly drawn, I've drawn myself, minus, plus, minus shit... The subject correctly identified only number 8 , she reacted with aggression at another attempt: (eight) Eight... maybe here. (Please point to number 9) [the subject pushed the book away] I need no stinky nine shitting her ass and stinking..., she did not finish the sentence.

The patient was unable to do text exercises of complex logical, semantic and grammatical structure, although she managed to retain in memory part of the data necessary to accomplish the task, e.g. (There were 3 books on a shelf and twice as many books on another shelf. How many books were there in total?) there were three books on a shelf like three books are three books spinning in a lesson that should be well said and explained, as one monkey is one and the rest is six. The subject failed to notice the purpose of the operation and the subsequent elements, i.e. the general plan and the executive part requiring quasi-spatial operations, were consequently disintegrated [see Łuria, 1976]. 


\section{Assessment of reading}

The subject named correctly most of the letters of the alphabet presented to her (87\%), she made several the so-called realization mistakes, giving names which sound similar, e.g. she confused $(f)$ with $(v)$, or she did not recognize the pattern, confusing (l) with (t).

There were few phonetic distortions in the texts read by the subject and she did not correct her own mistakes. The pace of reading was normal. In general, no suprasegmental disturbances were observed.

The patient read structural neologisms correctly without disruption. The ability to read them is regarded as a measure of pure phonological processing (the subject may not compensate difficulties with the use of lexical or grammatical knowledge).

In the test consisting in indicating a correctly written word among the incorrectly written ones, the basic deficiency concerned the understanding of the instruction heard, which is why the subject did not perform the task: (Please indicate the word which is spelled correctly: arkward, arwkwad, awkward) Arkward, arkward, what is this arkward? Arkward, arwkwad, awkward... (Which word is spelled correctly?) Well... one after another they are twisted in half, half the situation, this scene they are writing about there...; (Please indicate the word which is spelled correctly: ventiratol, ventilator, venatalator): ventilator, ventilator, ventalator... (Which word is spelled correctly?) eee... None of these three stupid as a cow on the street.

There was a clear disproportion between loud reading and reading with understanding, particularly on the level of sentences, short texts or instructions [Marczewska, 1994; Domagała, 2017]. The subject she was slightly better at reading words than texts, which indicates a disturbance of the mechanism of searching word verses with her eyes [see Domagała, 2017].

During the whole diagnostic process the patient was observed to display some kind of user behavior: the subject reads everything (mostly without understanding).

\section{Assessment of writing}

The subject was unwilling to complete writing tests, (rewriting, dictation, spontaneous writing and writing automated formula). In general, she did not start the tasks or resigned from completing them in the course of the activity, rejecting the notebook. If attempts to make her write were successful, she did it with great care, which is a sign of her relatively well preserved graphomotor skills (see photographs 1-3). However, there was a noticeable increase in the size of the writing, which may be connected with deterioration of eyesight, less ease and smooth running of the line [see Widła, 1986; Domagała, 2017]. There was no decrease in the legibility of the writing. Graphical and spelling mistakes appeared in words longer than 3 syllables which contained consonant clusters. She mostly used spelling and her writing was nonphonetic (see photograph 1). 


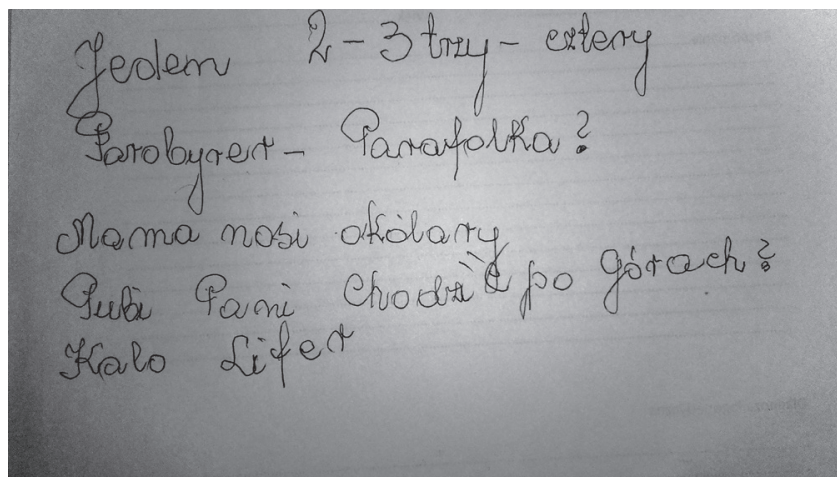

Photograph 1. Writing tests. The first sentence was rewritten by the subject, the second was dictated, below the spelling of the word kaloryfer [radiator in Polish]

Syntactical and morphological errors were observed in spontaneous writing 8 . The subject only wrote a short phrase in a test of creative writing.

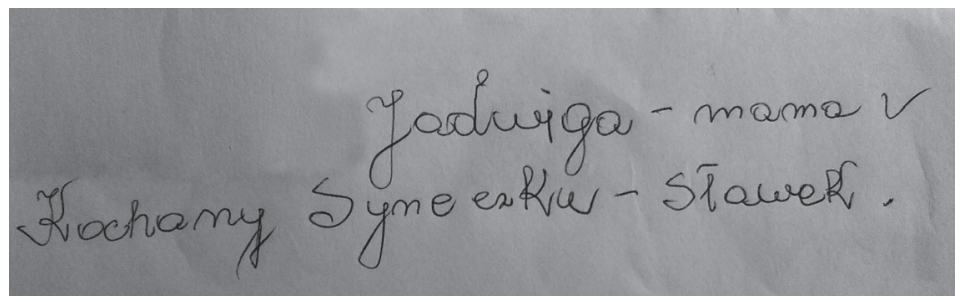

Photograph 2. A test of spontaneous writing

In the task checking the skill to reproduce formalized texts, the patient constructed correctly only the greeting formula and was not able to use the imposed scheme (a postcard with a place to write greetings and address).

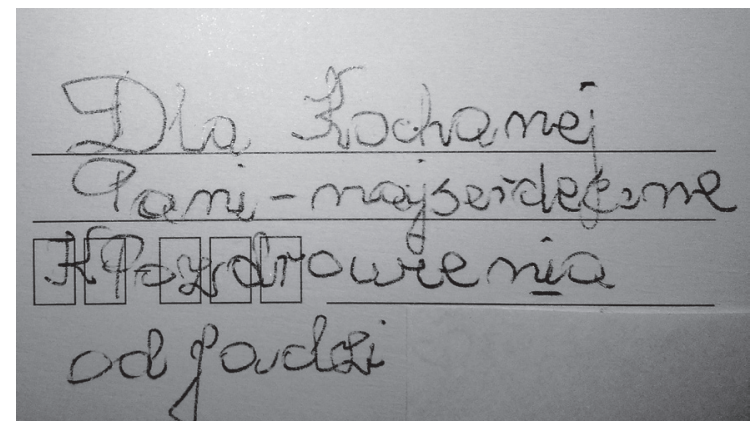

Photograph 3. A test of automated writing

8 The correctness of using punctuation was not assessed due to the inability to account for longer text samples of the subject written before the onset of the disease. 


\section{The body schema, left-right orientation}

No significant disturbances were observed in the recognition of the body schema in the patient ${ }^{9}$. In general, correctly pointed to her own body parts and those in the presented illustration even though she quite often related the instructions to herself, e.g. [the subject was shown an illustration presenting the head of a woman], (Please indicate her head, where is her head?) In her arse, in her arse, in her head... [at the same time the subject correctly points to her head and bottom]; (legs) I don't know her and show her to believe in stupidities... [the subject correctly points to her legs]; (arms) She lowered them above the grain level... [the subject correctly points to her arms]; (nose) She lengthened her nose to her mouth... (the subject correctly points to her face). The subject did not succeed in recognizing the left and right side.

\section{Assessment of oral praxis}

The subject performed only $25 \%$ of instructions, she quickly lost motivation and abandoned the subsequent tasks. Example reactions of the patient may be found below: (Please lick your lips with your tongue): [the subject did not do the test, she only commented:] Grossly smelly bang... (Please smack) I don't play the stupid hag! In all probability the reason for not doing the task and the aggressive reaction was the lack of motivation as well as disorders in understanding the oral instruction.

\section{Speech therapy diagnosis}

The functioning of the subject is determined by disorders in the emotional sphere whereas the lack of efficient motivational mechanisms contributes to the loss of interest in the surroundings and any activities, including speech therapy rehabilitation. The subject is incapable of satisfying her own needs, she is unable to plan basic activities, which points to seriously impaired executive mechanisms. Her functioning is handicapped by concentration disorders, reduced pace of processing information, limited ability to think abstractly on the verbal material and reduced efficiency of learning [see Dominguez, De Strooper, 2002].

Her messages are loud, emphatic, rather fast-paced, sometimes difficult to interrupt. Her utterance include elements of speech which is artificial, pompous, complaisant, excessively formal, at times even preacher's speech, utterances with excessively rigid syntax juxtaposed with vulgar wordings combined with physical aggression.

First of all, the subject's speech is characterized by a breakdown of the coherence of the text (dialogue, narration), illogicality and distraction. She is able to achieve 'the natural ending of the text' only in short 2-4-word sentences. On the level of longer sentences (which the subject does not avoid) the text is broken down often in a way which is inconsistent with grammar rules. The patient formulates sentences

9 Disorders in the recognition of the body schema are usually observed in case of parietal lobe damage, they may also concern left-right side assessment [cf. Szumska, 1980]. 
containing threads which are unconnected with one another and she juxtaposes them without creating logical connections in meaning. Longer sentence structures often lack content words or the so-called gluing words (conjunctions, pronouns). The impression of text deconstruction is exacerbated by the phenomenon of lack of word readiness. The sentences which she constructs are either too abstract or excessively concrete.

Neologisms, semantic and phonetic paraphrases are often used by the subject while descriptive constructions are rather rare. Echolalia was not observed. In the subject's speech there were visible moments of stuttering, repetition of word sounds and vocal paraphrases. The subject, however, does not speak when nobody listens to her.

In addition, the patient displays slight disorders of the motor mechanisms of pronunciation which are probably involutional in character.

\section{Logopaedic diagnosis}

On the basis of an anlaysis of medical documentation, the interview and logopedic examination of the patient diagnosed with of the frontal psychoorganic syndrome, disorders are found in the area of interaction, communication and language competences and skills.

The assessment of interaction competences and skills of the patient indicated slight disorders of understanding of non-verbal kinetic behavior and significant proximal disorders [see Grabias, 1997]. The subject uses non-verbal communication quite skilfully ${ }^{10}$. Considerable dysfunctions can be observed with reference to understanding verbal behaviours.

Pathological changes can be also observed in the area of communication competences and skills. The subject understands and uses social and situational principles to a comparable degree. Considerable impairment can be observed with regard to pragmatic skills and competences, the patient is unable to gain an advantage or reach a goal, using verbal communication.

The assessment of language competences and skills indicated that the patient recognizes the units of the phonological system, is capable of realizing them, she also recognizes and uses prosodic features correctly. Disorders are observed with regard to units of the morphological subsystem (lexis, word formation or inflection). The subject retained the ability to understand and formulate simple syntactic constructions. She is incapable of understanding or conducting metalinguistic operations.

Significant disorders are also observed in other language activities, such as reading comprehension (the ability to read alone has been preserved quite well), performing arithmetic operations on abstract sets or writing.

10 See The Scale of Non-verbal Communication [Pąchalska, 2012, p. 397]. 


\section{Therapeutic programme}

For several years, the literature has been questioning the widely accepted view on the irreversibility of organic changes within the brain. Recent studies suggest that the therapy of people with diagnosed organic disorders can have measurable effects [see Wysokiński et al., 2008; Panasiuk, 2015a, pp. 1048-1049].

Taking into account the patient's advanced level of dementia and her old age, the prognosis is not very good yet it cannot be excluded that the therapeutic proceeding will bring measurable effects. It should result in relative normalization of the patient's functioning, primarily in family relations but also in the social context.

Multi-specialist therapeutic effects (as only such effects can bring positive results in the case of the psychoorganic syndrome) should be aimed at stimulating interaction, communication and language behaviours.

The speech therapy should involve improving such aspects of linguistic functioning as: cognitive interpretation of the world, emotional assessment of reality as well as rules of verbal and non-verbal behaviour, taking into account social, situational and pragmatic conditions of communication [see Panasiuk, 2015a, pp. 1049-1050]. In the initial stage it is assumed that restitution and then compensation and adaptation strategies will be used. In order to improve the patient's linguistic functioning, firstly exercises aimed at improving the most disturbed language skills will be introduced, which will be followed by improving these skills in the context of various, either created or spontaneous, life situations [see Panasiuk, 2015a, p. 1050].

Individual therapy is also aimed at preparing the subject for the possible use of group occupational therapy (even though few patients staying in their own homes use such a form of rehabilitation, proposed e.g. by day care homes).

The purpose of indirect therapy is, among other things, to make the family and the closest environment of the patient aware of the actions to be taken in order to support her in overcoming further limitations and how to use everyday situations to achieve therapeutic goals. It is assumed that techniques of a practical nature should be applied so that the patient can use them in her daily activity.

\section{Conclusion}

The paper presents a speech therapy case study of a patient diagnosed with the psychoorganic syndrome manifested by disorders in the behaviour and its control, emotional, personality, language and memory disorders as well as disorders concerning criticism and thinking, including reasoning, abstracting and planning. The degree of the changes is so advanced that the subject is no longer capable of taking care of her basic needs. The observed background of the disturbance of interactive communication and language behaviour is psychogenic and neurological. 
References

Bilikiewicz A., Strzyżewski W., 1992, Psychiatria. Podręcznik dla studentów medycyny, Warszawa: Wydawnictwo Lekarskie PZWL.

Domagała A., 2007, Zachowania językowe w demencji, series "Komunikacja Językowa i Jej Zaburzenia", vol. 20, S. Grabias (ed.), Lublin: Wydawnictwo Uniwersytetu Marii CurieSkłodowskiej.

Domagała A., 2015, Narracja i jej zaburzenia w otępieniu alzheimerowskim, Lublin: Wydawnictwo Uniwersytetu Marii Curie-Skłodowskiej.

Domagała A., 2017, Zaburzenia komunikacji pisemnej u osób z chorobą Alzheimera, [in:] A. Domagała, U. Mirecka (eds.), Zburzenia komunikacji pisemnej, Gdańsk: Harmonia, pp. 524-545.

Dominguez D.I., De Strooper B., 2002, Novel therapeutic strategies provide the real test for the amyloid hypothesis of Alzheimer's disease, "Trends in Pharmacological Sciences", no. 23, pp. 324-330.

Goodglass H., Kaplan E., 1972, Boston Diagnostic Aphasia Examination, Philadelphia: Lea \& Febiger.

Grabias S., 1997, Język w zachowaniach społecznych, Lublin: Wydawnictwo Uniwersytetu Marii Curie-Skłodowskiej.

Grabias S., 2015, Postępowanie logopedyczne. Standardy terapii, [in:] S. Grabias, J. Panasiuk, T. Woźniak (eds.), Logopedia. Standardy postępowania logopedycznego, Lublin: Wydawnictwo Uniwersytetu Marii Curie-Skłodowskiej, pp. 955-995.

Herzyk A., 2005, Wprowadzenie do neuropsychologii klinicznej, Warszawa: Wydawnictwo Naukowe Scholar.

ICD-10, 2008, Międzynarodowa Statystyczna Klasyfikacja Chorób i Problemów Zdrowotnych ICD-10, www.csioz.gov.pl/interoperacyjnosc/klasyfikacje (accessed: 28.03.2019).

Jodzio K., 2006, Neuropoznawcze korelaty spadku fluencji słownej po udarze prawej półkuli mózgu, "Studia Psychologiczne", vol. 44(2), pp. 5-18.

Jodzio K., 2008, Neuropsychologia intencjonalnego działania. Koncepcje funkcji wykonawczych, Warszawa: Wydawnictwo Naukowe Scholar.

Kielar-Turska M., Byczewska-Konieczny K., 2014, Specyficzne właściwości posługiwania się językiem przez osoby w wieku senioralnym, [in:] S. Milewski, J. Kuczkowski, K. Kaczorowska-Bray (eds.), Biomedyczne podstawy logopedii, Gdańsk: Harmonia, pp. 429-443.

Kozubski W., Liberski P.P., 2014, Neurologia. Podręcznik dla studentów medycyny, Warszawa: Wydawnictwo Lekarskie PZWL.

Krzymiński S., 1995, Test rysowania zegara, "Postępy Psychiatrii i Neurologii”, no. 4, supplement I(2), pp. 21-30.

Łuria A.R., 1976, Podstawy neuropsychologii, Warszawa: Wydawnictwo Lekarskie PZWL.

Marczewska H., 1994, Zaburzenia językowe w demencji typu Alzheimera i demencji wielozawałowej, [in:] H. Marczewska, E. Osiejuk (eds.), Nie tylko afazja... O zaburzeniach językowych w demencji Alzheimera, demencji wielozawałowej i przy uszkodzeniach prawej półkuli mózgu, Warszawa: Energeia, pp. 7-60.

Olszewski H., 2008, Otępienie czołowo-skroniowe. Ujęcie neuropsychologiczne, Kraków: Oficyna Wydawnicza Impuls.

Panasiuk J., 2013, Afazja a interakcja. Tekst - metatekst - kontekst, Lublin: Wydawnictwo Uniwersytetu Marii Curie-Skłodowskiej. 
Panasiuk J., 2015a, Postępowanie logopedyczne w przypadku zespołu psychoorganicznego, [in:] S. Grabias, J. Panasiuk, T. Woźniak (eds.), Logopedia. Standardy postępowania logopedycznego, Lublin: Wydawnictwo Uniwersytetu Marii Curie-Skłodowskiej, pp. 1025-1058.

Panasiuk J., 2015b, Zespół psychoorganiczny w diagnozie logopedycznej, “Logopedia Silesiana”, no. 4, pp. 81-112.

Pąchalska M., 2012, Afazjologia, Warszawa-Kraków: Wydawnictwo Naukowe PWN.

Piskunowicz M., Bieliński M., Zgliński A., Borkowska A., 2013, Testy fluencji słownej - zastosowanie w diagnostyce neuropsychologicznej, "Psychiatria Polska”, vol. XLVII, no. 3, pp. 475-485.

Prusiński A., 1998, Neurologia praktyczna, Warszawa: Wydawnictwo Lekarskie PZWL.

Schulman K.L., Shedletsky R., Silver I.L., 1997, The Challenge of Time: Clock Drawing and Cognitive Function in the Elderly, "International Journal of Geriatric Psychiatry" vol. 1, issue 2, pp. 619-627.

Sitek E.J., Konkel A., Międzobrodzka E., Sołtan W., Barczak A., Sławek J., 2014, Kliniczne zastosowanie prób fluencji słownej w chorobie Huntingtona, "Hygeia Public Health", vol. 49(2), pp. 215-221.

Siuda J., Opala G., 2012, Diagnostyka różnicowa otępienia, [in:] M. Zabawa (ed.), Diagnostyka i leczenie otępień. Rekomendacje zespołu ekspertów Polskiego Towarzystwa Alzheimerowskiego, Otwock: MediSfera, pp. 41-49.

Szepietowska E.M., 2000, Badanie neuropsychologiczne. Procedura i ocena, Lublin: Wydawnictwo Uniwersytetu Marii Curie-Skłodowskiej.

Szepietowska E.M., Gawda B., 2011, Ścieżkami fluencji werbalnej, Lublin: Wydawnictwo Uniwersytetu Marii Curie-Skłodowskiej.

Szepietowska E.M., Lipian J., 2012, Fluencja słowna neutralna i afektywna u chorych z uszkodzeniem prawej, lewej lub obu półkul mózgu, "Psychiatria Polska", vol. XLVI, no. 4, pp. 539-551.

Szumska J., 1980, Metody badania afazji, Warszawa: Wydawnictwo Lekarskie PZWL.

Warchala J., 1991, Dialog potoczny a tekst, Katowice: Wydawnictwo Uniwersytetu Śląskiego.

Widła T., 1986, Cechy płci w piśmie ręcznym, Katowice: Wydawnictwo Uniwersytetu Śląskiego.

Woźniak T., 2005, Narracja w schizofrenii, Lublin: Wydawnictwo Uniwersytetu Marii CurieSkłodowskiej.

Woźniak T., 2014, Zaburzenia mowy w schizofrenii, [in:] S. Grabias, M. Kurkowski (eds.), Logopedia. Teoria zaburzeń mowy, Lublin: Wydawnictwo Uniwersytetu Marii Curie-Skłodowskiej, pp. 645-677.

Wysokiński A., Orzechowska A., Strombek-Milczarek M., Gruszczyński W., 2008, Odwracalność zaburzeń psychopatologicznych po stłuczeniu mózgu - przypadek kazuistyczny, "Psychiatria w Praktyce Klinicznej", vol. 1, pp. 46-49. 


\section{Abstract}

The psychoorganic syndrome is a deviation in the mental state due to damage or dysfunction of the brain structures. It is associated with the occurrence of mental disorders manifested in the behavioral, socio-emotional, cognitive and therefore also communicative sphere. The article describes the case of a 68 -year-old patient who was diagnosed with the psychoorganic syndrome. The changes observed in her relate to significant dysfunctions in the areas of competence, interaction, communication and language.

\section{Streszczenie}

Zespół psychoorganiczny to odchylenie w stanie psychicznym, uwarunkowane uszkodzeniem lub dysfunkcją struktur mózgu. Wiąże się on z występowaniem zaburzeń psychicznych, przejawiających się w sferze behawioralnej, społeczno-emocjonalnej, poznawczej, a także komunikacyjnej. W artykule opisano przypadek 68-letniej pacjentki, u której rozpoznano zespół psychoorganiczny. Obserwowane u niej zmiany dotyczą znacznych dysfunkcji w zakresie kompetencji i sprawności interakcyjnych, komunikacyjnych i językowych. 